\title{
Combining genetically engineered oxidase with hydrogen bonded organic framework (HOF) for highly efficient biocomposites.
}

\author{
Peter Wied, ${ }^{[a, b]}$ Francesco Carraro, ${ }^{[b]}$ Juan M. Bolivar, ${ }^{[a]}$ Christian J. Doonan, ${ }^{*[c]}$ Paolo Falcaro ${ }^{*[b]}$ and \\ Bernd Nidetzky*[a]
}

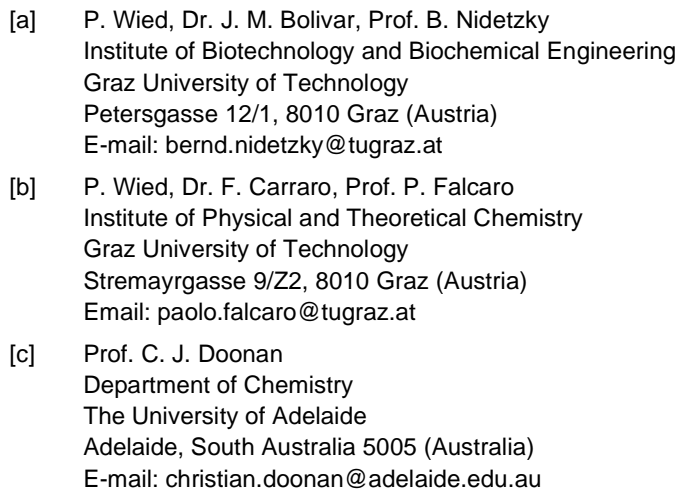

\begin{abstract}
Hydrogen bonded organic frameworks (HOFs) with enzymes incorporated during their bottom-up synthesis represent functional biocomposites with promising applications in catalysis and sensing. High enzyme loading while preserving high specific activity is fundamental for development, but to combine these biospecific features with a porous carrier is an unmet challenge. Here, we explored synthetic incorporation of D-amino acid oxidase (DAAO) with metal-free tetraamidine/tetracarboxylate-based BioHOF-1. Comparison of different DAAO forms in BioHOF-1 incorporation revealed that $\mathrm{N}$-terminal enzyme fusion with the positively charged module $Z_{\text {basic2 }}\left(Z\right.$-DAAO) promotes the loading (2.5-fold; $~ 500 \mathrm{mg} \mathrm{g}^{-1}$ ) and strongly boosts the activity $(6.5$-fold). To benchmark the HOF composite with metal-organic framework (MOF) composites, Z-DAAO was immobilized into the zeolitic imidazolate framework-8 (ZIF-8), the relatively more hydrophilic analogue metal azolate framework-7 (MAF-7). While sensitivity to the framework environment limited the activity of DAAO@MAF-7 (3.2 U mg $\left.{ }^{-1}\right)$ and DAAO@ZIF-8 ( $\leq 0.5 \mathrm{U} \mathrm{mg}$ $\left.{ }^{1}\right)$, the activity of DAAO@BioHOF-1 was comparable ( 45\%) to that of soluble DAAO $\left(50.1 \mathrm{U} \mathrm{mg}^{-1}\right)$ and independent of the enzyme loading $\left(100-500 \mathrm{mg} \mathrm{g}^{-1}\right)$. The DAAO@BioHOF-1 composites showed superior activity with respect to every reported carrier for the same enzyme and excellent stability during solid catalyst recycling. Collectively, our results show that the fusion of the enzyme with a positively charged protein module enables the synthesis of highly active HOF biocomposites suggesting the use of genetic engineering for the preparation of biohybrid systems with unprecedented properties.
\end{abstract}

\section{Introduction}

The application of enzymes to modern industrial processes ${ }^{[1-3]}$ and therapeutics ${ }^{[4,5]}$ demands progress in research aimed at tailoring enzyme functionality and developing methodologies for their integration into devices. ${ }^{[6-10]}$ Like most non-fibrous proteins, enzymes are inherently fragile ex situ, hindering their use, for example, in commercial catalysis where recyclability is desired. ${ }^{[11-}$ 13] Thus, immobilization on, or within, solids is employed as a strategy to enhance enzyme stability in catalysis, biomedical science and biosensing applications. ${ }^{[6,8,14-21]}$ For example, infiltration into preformed porous materials (e.g., silica, organic polymers) is well known for enzyme immobilization. ${ }^{[20,22,23]}$ A key challenge in the synthesis of such biocomposites is to achieve high enzyme loading on the surface of the solid while its retaining biological activity.[21,24-27]

Porous crystalline frameworks such as metal-organic frameworks (MOFs) and hydrogen-bonded organic frameworks (HOFs) ${ }^{[28,29]}$ are a class of solids assembled in a modular fashion and thus allow for precise control of their structures through the judicious choice of the building blocks. Whereas MOFs consist of metal nodes and organic linkers, HOFs are assembled through hydrogen bonding of organic components. ${ }^{[30]}$ These materials offer unique opportunities to promote enzyme immobilization beyond the limits of traditional carrier-based approaches ${ }^{[8,31-35]}$ as their bottom-up synthesis can be carried out under enzymecompatible incubation conditions. Thus, biocomposites that preserve the active enzyme into the porous solids framework can be realized. ${ }^{[8,32,33]}$ Indeed, MOF- and HOF-based composites have been reported for a number of enzymes and several show promise as biocatalysts with high specific activity, stability and recyclability. ${ }^{[32,33,36,37]}$ Recent seminal studies in HOF biocomposites have shown very high protein loading. ${ }^{[3]}$ In this case the protein surface was chemically modified to enhance its positive charge, yielding favorable interactions with the carboxylate-based HOF building blocks. ${ }^{[37,38]}$ Although this approach resulted in high enzyme loading, protein surface functionalization protocols require multistep procedures, ${ }^{[37,39,40]}$ depend on the specific sequence of amino acids and their accessibility, ${ }^{[41]}$ and can influence the native bioactivity. ${ }^{[42]} A$ strategy that has been overlooked to increase protein-framework interactions is protein engineering, where progress in both molecular biotechnology and DNA manipulation has enabled a straightforward and cost-effective expression of fused protein systems. ${ }^{[43-45]}$ For example, enzymes can be expressed with arginine-rich mini-proteins (modules) connected by a polypeptide chain $\left(Z_{\text {basic2 }}\right.$ made of 58 amino acid; $7 \mathrm{kDa}$ ) to improve noncovalent immobilization on inorganic substrates. ${ }^{[46]}$ We hypothesize that such positive surface charge enrichment via $\mathrm{Z}_{\text {basic2 }}$ modules would enhance the protein immobilization in HOFs (Figure 1a). 
Here, we report a detailed study of biocomposites prepared via mixing $Z_{\text {basic2 } 2}$ functionalized $\mathrm{D}$-amino acid oxidase (Z-DAAO; Figure 1b) and BioHOF1 precursors (tetraamidinium and tetracarboxylate linkers) in water (Figure 1c). DAAO was selected due its broad relevance in industrial bio-catalysis ${ }^{[15,47]}$ and due to its potential applications in analytics and medicine. ${ }^{[48,49]}$ For comparison, Z-DAAO biocomposites were prepared from two MOF materials that are known to immobilize enzymes via an analogous one-pot approach; Zeolitic Imidazolate Framework 8 (ZIF-8, composed of $\mathrm{Zn}^{2+}$ and 2-methyilimidazole, 2-mIM) and a structurally analogous but more hydrophilic material Metal Azolate Framework 7 (MAF-7, composed of $\mathrm{Zn}^{2+}$ and 3methyl-1,2,4-triazole,mtz; Figure 1c). This comparison allowed us to benchmark the performance characteristics of the HOFbased biocomposite to those of the well-studied ZIF-based analogues. In summary, we show that $Z_{\text {basic2 }}$ functionalization enhances DAAO immobilization in/on BioHOF-1 and that the resulting enzymatic activity of the Z-DAAO@BioHOF-1 significantly outperforms Z-DAAO@ZIF-8, Z-DAAO@MAF-7 and all previously reported DAAO composites. Thus, we envision that protein engineering will offer new opportunities for the synthesis of efficient HOF-based composites for enzyme applications.

(a)

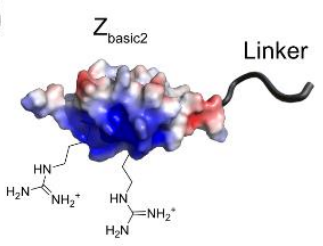

(b)

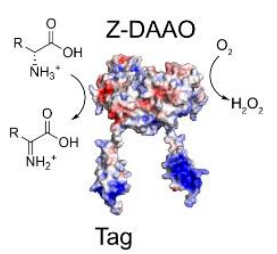

(c)
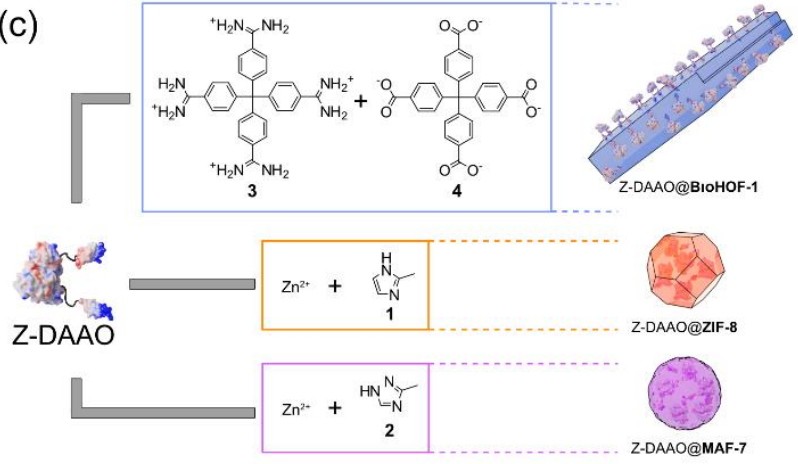

Figure 1. (a) $Z_{\text {basic } 2}$ binding module and clustered arginine residues. A structural model of D-amino acid oxidase from Rhodotorula toruloides and the fused $Z_{\text {basic } 2}$ tag was created using The PyMOL Molecular Graphics System, Version 2.6 Schrödinger, LLC. Surface charge visualization was calculated using APBS software ${ }^{[50]}$. (b) Schematic representation of Z-DAAO dimer catalyzing the deamination of $D$-amino acids. (c) Precursors used for the one-pot and waterbased synthesis of each biocomposite (Z-DAAO@BioHOF-1, Z-DAAO@ZIF-8, and Z-DAAO@MAF-7).

\section{Results and Discussion}

Native DAAO ${ }^{[51,52]}$ from Trigonopsis variabilis $(78 \mathrm{kDa}$, homodimer) and DAAO fused with the cationic binding module $\mathrm{Z}_{\text {basic2 }}(7 \mathrm{kDa})^{[53]}$, here referred to as Z-DAAO, were purified from an Escherichia coli expression culture (see SI_I1). The addition of the positively charged $Z_{\text {basic2 }}$ module confers affinity for binding to negatively charged surfaces and has been employed to facilitate immobilization on solid supports (e.g., porous silica) and to control biomolecular orientation. ${ }^{[53-57]}$ In this study we tested both native DAAO and Z-DAAO for the one-pot preparation of HOF and ZIFbased biocomposites, here denoted as DAAO@BioHOF-1, ZDAAO@BioHOF-1.

Addition of DAAO and Z-DAAO (1.0 mg ml $\left.\mathrm{m}^{-1}\right)$, respectively, to a solution of BioHOF-1 precursors (tetraamidinium and tetracarboxylate linkers), yielded the rapid formation of a solid precipitate. Close inspection of the precipitate via optical microscopy revealed that the precipitate was comprised of high aspect ratio particles. We note such particle morphology is typical of BioHOF-1 composites (Figure S5). ${ }^{[36]}$ The samples were then centrifuged and the enzyme loading and activity were determined. For DAAO@BioHOF-1, only $42.7 \%$ of the protein was immobilized (see protein yield, $Y_{\mathrm{P}}$, aka encapsulation efficiency $E E$, Figure 2) whereas fusion of the $Z_{\text {basic2 }}$ module in Z-DAAO engendered a $Y_{P}$ of $100 \%$. Enzyme activity was measured using the DAAO assay (see supporting information, SI_I10). As control experiment, we performed the DAAO assay on each of the supports and each showed zero activity in the absence of the enzyme. Notably, Z-DAAO@BioHOF-1 resulted in nearly one order of magnitude increased retention of activity after immobilization (see activity yield, $\left.Y_{\mathrm{A}}, \mathrm{SI} \_113\right)^{[8]}$ compared to DAAO@BioHOF-1. Thus, the intrinsic activity of the bound enzyme compared to its free form (see effectiveness factor, $\eta$, SI_[13) ${ }^{[8]}$ was also increased 6.5-fold in Z-DAAO@BioHOF-1 vs. DAAO@BioHOF-1. These results suggest that the $Z_{\text {basic2 }}$ module is primarily responsible for the high enzyme loading and activity of observed for the Z-DAAO@BioHOF-1 composite.

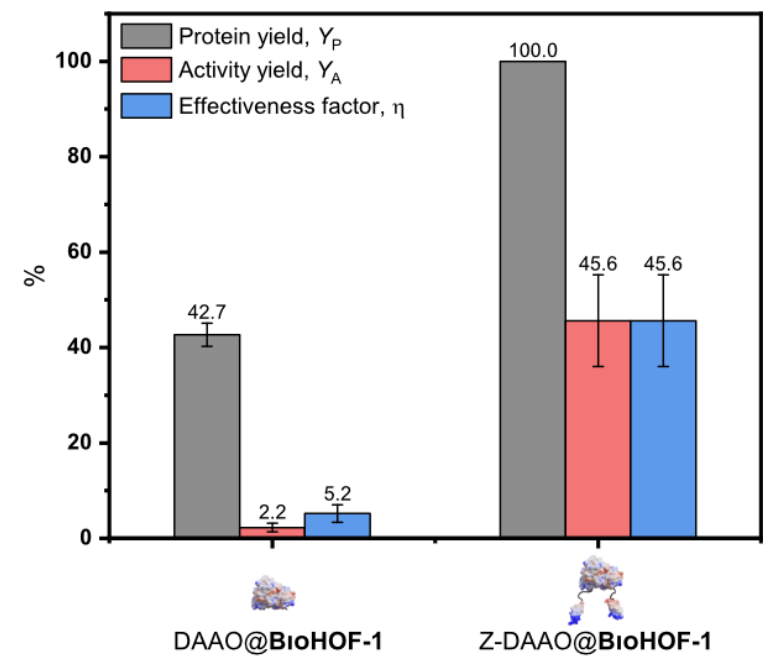

Figure 2. Immobilization performance of the HOF biocomposite prepared with the native enzyme (DAAO@BioHOF-1) and with the $Z_{\text {basic2 }}$ module engineered enzyme (Z-DAAO@BioHOF-1). Protein yield $\left(Y_{P}\right)$, Activity yield $\left(Y_{A}\right)$, and effectiveness factor $(\eta)$ are given in $\%$.

The positive charge on $Z_{\text {basic2 }}$ derives from several $A r g$ residues clustered on one side of the module's three-helical bundle structure (Figure 1a). ${ }^{[57]}$ The Arg guanidine group is chemically similar to the amidine groups of the cationic building block of the BioHOF-1. Thus we hypothesize that Z-DAAO incorporation into 
the nascent BioHOF-1 composite may involve a multivalent process whereby $Z_{\text {basic2 }}$ guanidine moieties bind to the exposed carboxylate groups of the HOF in place of tetraamidinium building units. ${ }^{[37]}$ This idea is in good agreement with examples of HOF composites that report superior $Y_{\mathrm{P}}$ for amino-modified model proteins (i.e., BSA and GFP), compared with pristine and carboxyl-modified proteins. ${ }^{[37,58]}$ The structures of the DAAO biocomposites were examined by X-ray diffraction (XRD), which revealed that the diffraction patterns of DAAO@BioHOF-1 and ZDAAO@BioHOF-1 were analogous to that of as-synthesized BioHOF-1 (see Figure S6 and Figure 3a). ${ }^{[36]}$

Next, we prepared Z-DAAO composites of ZIF-8 and, the isostructural but more hydrophilic, MAF-7 to benchmark the performance of Z-DAAO@BioHOF-1 to other porous biocomposites that can be prepared via one-pot methods in water. Employing reported protocols, ${ }^{[59]}$ for the synthesis of the ZIF-8 and MAF-7 biocomposites yielded Z-DAAO@ZIF-L[60] an amorphous product, respectively (Figure S7-S8). However, by modifying the synthesis conditions (e.g. metal-to-ligand ratio and concentration of ammonia), biocomposites of sodalite (sod)

(a)

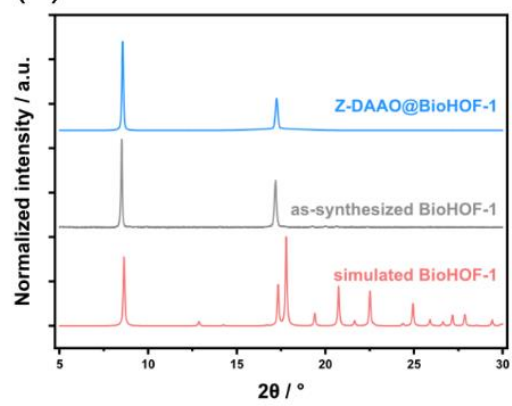

(d)

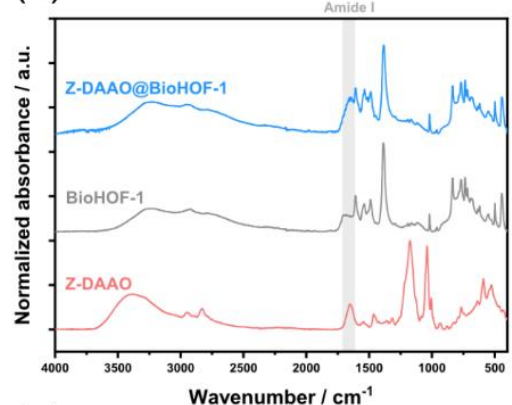

(g)

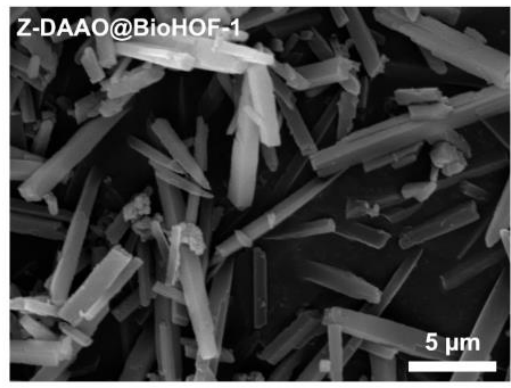

(b)

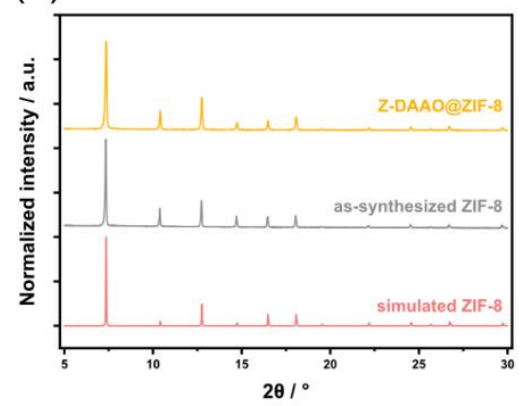

(e)

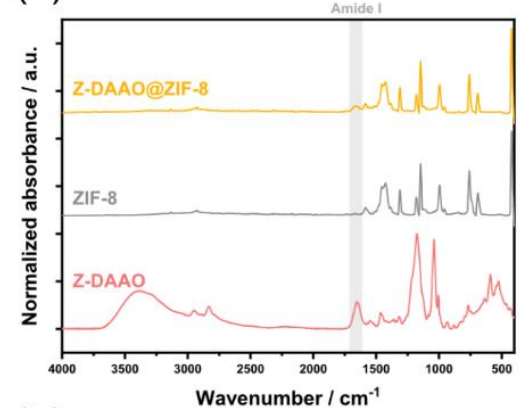

(h)

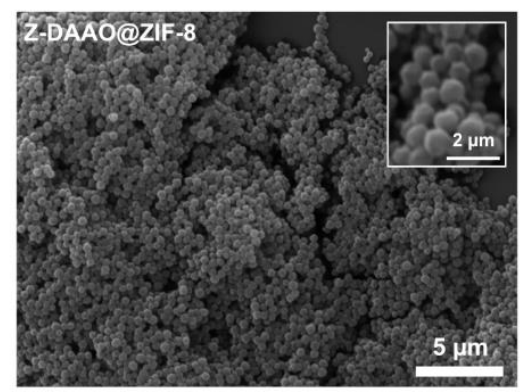

topology were obtained (see S9-S12, and Fig 3b-c). The sod topology (flexible framework with pore window of $3.4 \AA$ ) ensures accessible porosity and maximize mass diffusion. ${ }^{61-63]}$

To examine the chemical composition and confirm the presence of the enzyme in all composites, we used Fourier-transformed infrared (FTIR) spectroscopy (see Figure 3d-f). ZDAAO@BioHOF-1, Z-DAAO@ZIF-8 and Z-DAAO@MAF-7 composites each showed an absorbance band in the protein amide I region $\left(1700-1600 \mathrm{~cm}^{-1}\right)$ that was absent in pure framework and increased with enzyme loading (Figure S13S15). ${ }^{[64]}$ However, for Z-DAAO@ZIF-8, a bifurcation in the amide I vibrational band $\left(1650 \mathrm{~cm}^{-1}\right)$ is observed. This suggests the secondary structure of the enzyme is modified upon composite formation (Figure S16). ${ }^{65-69]}$

The particle size and morphology of the biocomposites were examined using scanning electron microscopy (SEM, see particle size analysis Figure S17-S26). Figure $\mathbf{3 g}$ shows that $Z$ DAAO@BioHOF-1 formed needle-like crystals of ca. $7 \mu \mathrm{m}$ with squared cross section of $700 \mathrm{~nm}$ in width,

(c)

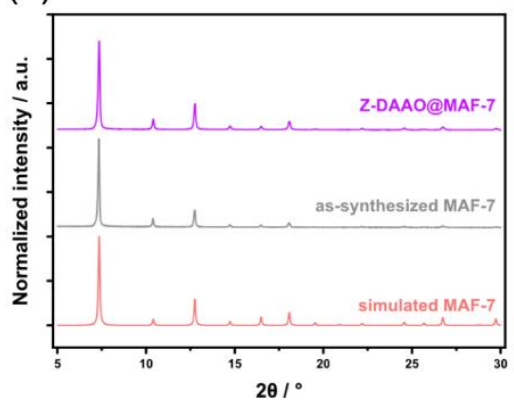

(f)

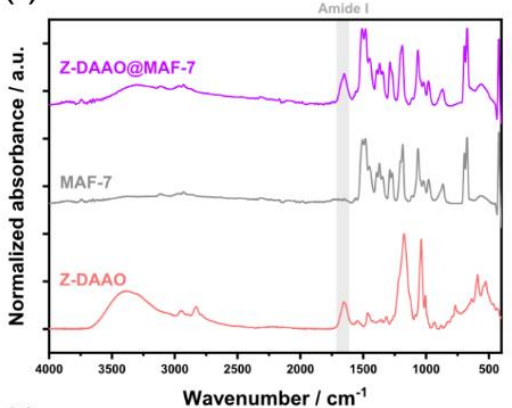

(i)

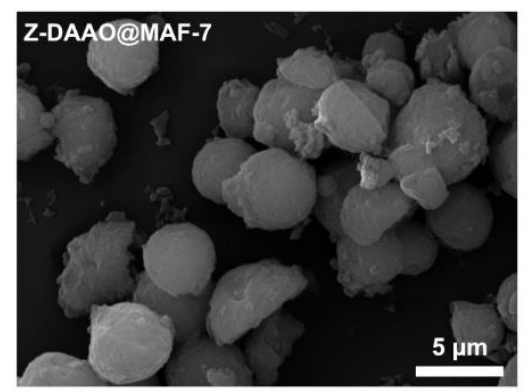

Figure 3. Material characterization of Z-DAAO@BioHOF-1, Z-DAAO@ZIF-8, and Z-DAAO@MAF-7 with an initial Z-DAAO concentration of 1 mg mL-1 during synthesis after optimization of the synthesis to obtain each material at the correct topology. (a-c) PXRD patterns including simulated PXRD patterns of each material (red), each material without biocatalyst (grey), and Z-DAAO@HOF/MOF. (d-f) ATR-FTIR spectra of each material with/without biocatalyst. (g-i) SEM images of the obtained biocomposites with inset zoom of Z-DAAO@ZIF-8 
Z-DAAO@ZIF-8 exhibited a rhombic dodecahedral morphology (Figure 3h) with average particle size of ca. $500 \mathrm{~nm}$ and ZDAAO@MAF-7 formed spherical particles (Figure 3i) of ca. 4.5 $\mu \mathrm{m}$ that presumably formed due to crystal inter-growth. We note that the presence of the enzyme in the synthesis did not influence the particle morphology of the different frameworks (Figure S17S19), however, a significant change in average particle size was noted only for pure MAF-7 (ca. 30\% decrease).

Next, the immobilization performance at varying initial Z-DAAO concentrations, during the biocomposite synthesis, was assessed. The framework integrity at all Z-DAAO loadings was confirmed by FTIR and XRD analyses (Figure S13-S15, S27-S29). Each of the biocomposites incorporated all of the Z-DAAO $\left(0.25-1.5 \mathrm{mg} \mathrm{ml}^{-}\right.$ 1) from solution into the solid material (see $Y_{\mathrm{P}}$ Figure 4a, Figure S30). Given that the protein yield is $100 \%$ for all three biocomposites $Y_{\mathrm{A}}=\eta$. The activity of the three materials varied significantly; Z-DAAO@BIOHOF-1 was highly active ( $\eta=45 \%$,), while Z-DAAO@ZIF-8 was inactive, likely due to the hydrophobic nature of the framework. ${ }^{[59]}$ Z-DAAO@MAF-7 retained partial activity with $\eta=8 \%$ (Figure S31). This could be ascribed to the enhanced diffusion through defects in the MAF-7 structure ${ }^{[70]}$ or possibly that the solid dissolved during the assay and the activity recorded may be the result of free enzyme (Figure S32).

Figure $\mathbf{4 b}$ compares the effective protein loading, considered a key parameter for bioreactor design, of the HOF and ZIF-based biocomposites along with traditional materials employed for DAAO immobilization. ${ }^{[71,72]}$ The DAAO@BioHOF-1 composite ( 0.55 genyzme $\left.\mathrm{g}_{\text {material }}{ }^{-1}\right)$ showed a higher effective loading than the two MOF materials and significantly exceeded the limits of traditional materials $\left(\sim 0.1 g_{\text {enyzme }} g_{\text {material }}{ }^{-1}\right)$. For example, ZDAAO@BioHOF-1 is ca. 7-fold higher than Z-DAAO@SBA-15. Furthermore, the exceptionally high loading for ZDAAO@BioHOF-1 corresponded to the highest specific activity (ca. $7500 \mathrm{U} \mathrm{g}^{-1}$ material). It is worth noting that enzymes of the $\mathrm{O}_{2}$ dependent class are challenging to process into highly active solid preparations. ${ }^{[73-76]}$

For $\mathrm{O}_{2}$ dependent enzymes, $\eta$ decreases sharply with increasing enzyme loading due to $\mathrm{O}_{2}$ depletion inside the porous catalyst. ${ }^{[76-}$ 79] This can be seen by the decrease of $\eta$ at increased specific activity $_{\text {material }}$ for silica-based support such as MSU-F and SBA-15 (see Figure 5a, Figure S33-S37). Enzyme composites showing increased $\mathrm{O}_{2}$ activity due to better balance between reaction and diffusion are thus desirable. ${ }^{[77]}$ The crystalline porous frameworks are promising in this respect due to their large pore volume and accessible porosity. To this end we examined $\eta$ vs. specific

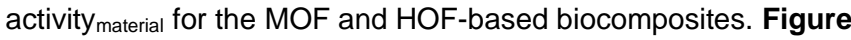
5a shows that Z-and DAAO@BioHOF-1 are highly active: 5.7-fold more active than the best MOF biocomposite (Z-DAAO@MAF-7) with a measured specific activity of $\sim 24 \mathrm{U} \mathrm{mg}_{\text {enzyme }}(\eta=\sim 45 \%)$. Remarkably, compared to traditional porous silica (MSU-F and SBA-15) ${ }^{[55,78]}$ or MAF-7, Z-DAAO@BioHOF-1 showed that $\eta$ is preserved even at higher enzyme loading (Figure S36-S37). Indeed, the high $\eta$ of the BioHOF-1 composite (higher than 45\%) results in a record value of specific activity per gram of material: 6 times higher than the best previously reported value for mesoporous silica (SBA-15) and ca. 12 times that of the hydrophilic MOF (MAF-7).
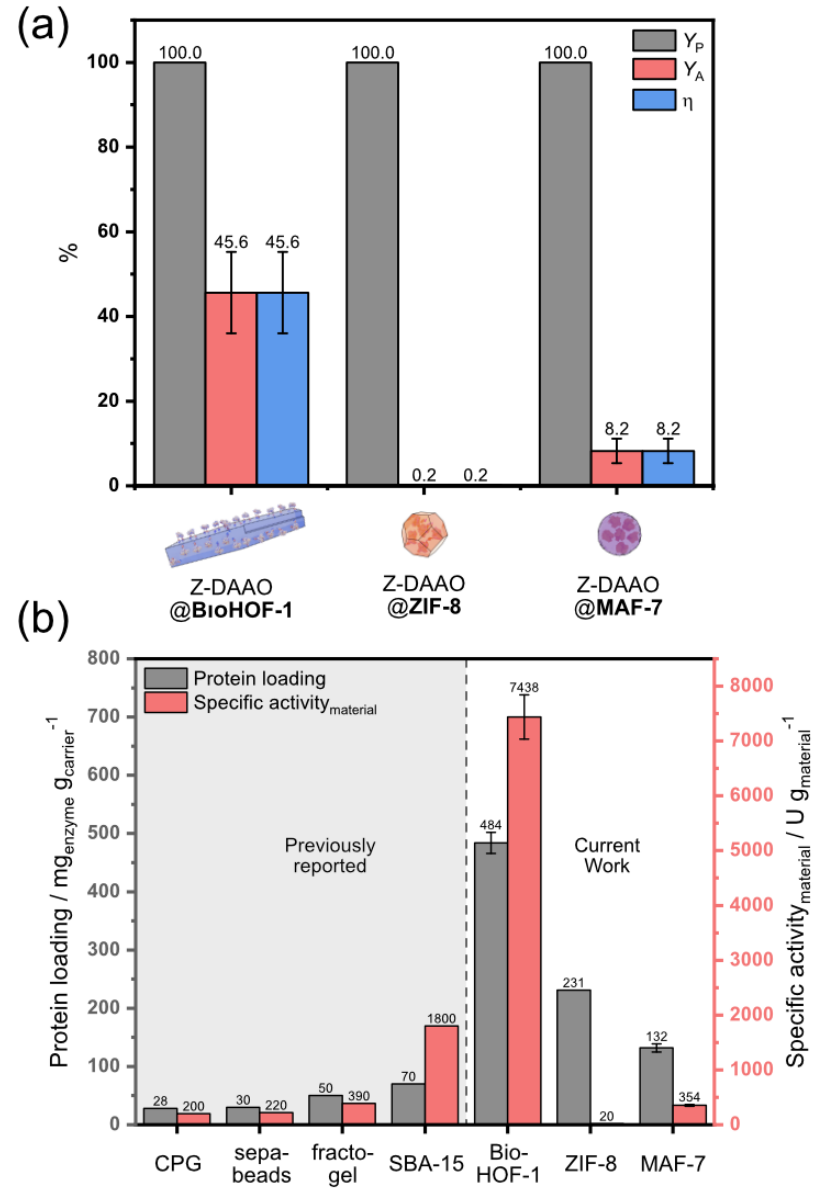

Figure 4. (a) The immobilization performance of Z-DAAO@BioHOF-1. Z DAAO@ZIF-8, and Z-DAAO@MAF-7 prepared with an initial Z-DAAO concentration of $1 \mathrm{mg} \mathrm{mL}^{-1}$ during the immobilization (values calculated averaging at least 3 different batches from biological replicates). Protein yield $\left(Y_{\mathrm{P}}\right)$, Activity yield $\left(Y_{\mathrm{A}}\right)$, and effectiveness factor $(\eta)$ are given in \%. (b) Protein loading and specific activity of DAAO@ZIF-8, DAAO@MAF7 and DAAO@BioHOF-1 (current work) compared to previously reported results of immobilized DAAO (grey): controlled pore glass (CPG) ${ }^{[54]}$, sepabeads ${ }^{[53]}$, fractoge ${ }^{[53]}$ and ordered mesoporous silica (SBA-15) ${ }^{[55]}$.

We posit that the record activity of Z-DAAO@BioHOF-1, can be attributed to the unique 1-D (needle-like) particle geometry of the composite. This morphology can provide a large surface-tovolume ratio which is favorable for external (liquid-to-solid) and internal diffusion via the micro-porous network. In addition, the spatial distribution of immobilized enzymes in/on carriers may play a crucial role. ${ }^{[80,81]}$ To distinguish between the externally and internally bound enzyme, we used tryptic digestion to inactivate the Z-DAAO. Substantial loss (>90\%) of Z-DAAO@BioHOF-1 activity on incubation with trypsin revealed that the major portion of the immobilized Z-DAAO was protease-accessible, hence at least partially exposed to external surface of the particles (Figure S38). Importantly, the performance characteristics of the ZDAAO@BioHOF-1 composite could not be reproduced by a simple adsorption of the Z-DAAO on a pre-synthesized BioHOF1 framework (Figure S39). The enzyme binding to the solid was decreased strongly $(>70 \%)$ and the specific activity of the immobilized Z-DAAO lowered to a similar degree (>70\%) as compared to Z-DAAO@BioHOF-1 synthesized via the one-pot approach. Overall, the comparison between $\eta$ for the adsorption of the Z-DAAO on BioHOF-1 and one-pot preparations of DAAO@BioHOF-1 and Z-DAAO@BioHOF-1 (see Figure 2 and 
Figure S39) suggests that for the one-pot Z-DAAO@BioHOF-1 system the enzyme is partially embedded on the HOF surface. ${ }^{[55,82]}$ While this hypothesis requires further study beyond the current scope of the current work, it is evident that the incorporation of the $Z_{\text {basic2 }}$ module via rational protein engineering is a promising strategy for the development of framework-based enzyme composites. ${ }^{[11,83,84]}$ Nevertheless, the notion of partially embedded DAAO is consistent with kinetic studies that show a $K_{m}$ value for D-Met 2.2-fold lower in Z-DAAO@BioHOF-1 than soluble Z-DAAO as this implies a catalytic reaction for the immobilized Z-DAAO that is effectively unrestricted by diffusion (Table 1, Figure S40-S45). Slow diffusion into the solid catalyst would show as an increase in the apparent $K_{\mathrm{m}}$ (Figure S46). ${ }^{[23,76,85]}$ Decrease in the $K_{\mathrm{m}}$ might be explained by a favorable partitioning of the somewhat hydrophobic D-Met between the liquid phase and the solid surface of the composite. ${ }^{[86]}$ Remarkably, therefore, the catalytic efficiency $\left(k_{\text {cat }} / K_{\mathrm{m}}\right)$ of the ZDAAO@BioHOF-1 composite is close to that of the soluble enzyme. Consistent with this interpretation, the D-Met $K_{\mathrm{m}}$ of $Z$ DAAO@MAF-7 was comparable to that of the soluble enzyme suggesting that diffusional effects are negligible.

(a)

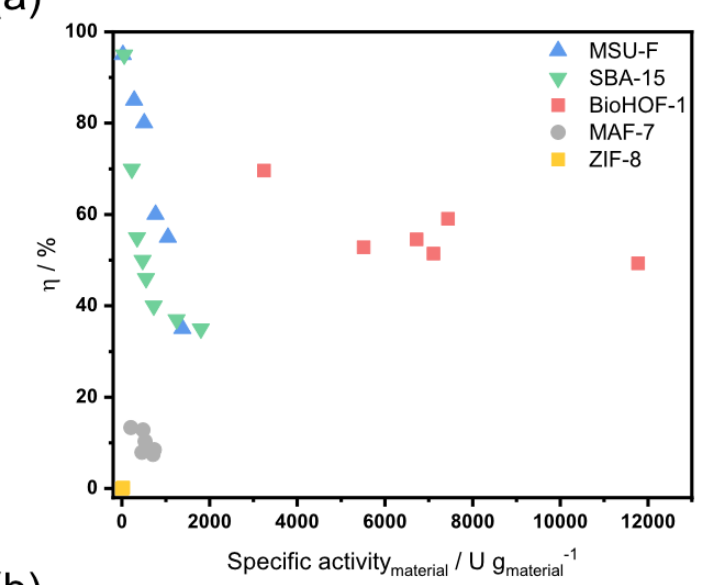

(b)

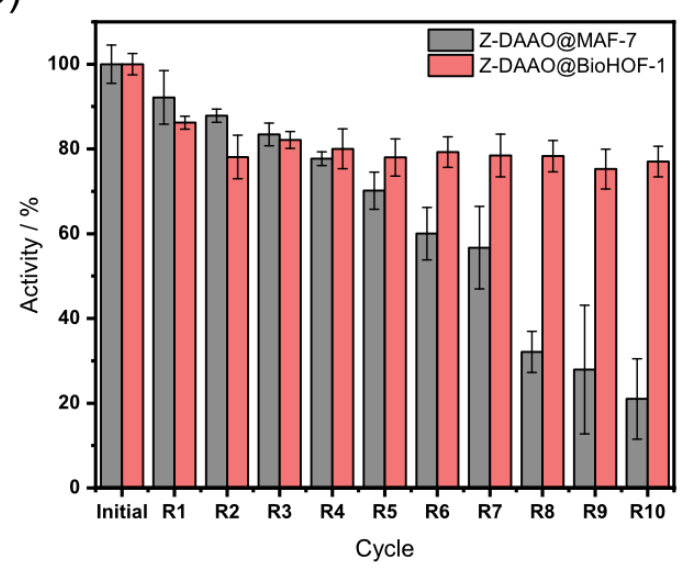

Figure 5. (a) Specific activitymaterial vs. effectiveness factor ( $\eta$ ) of ZDAAO@BioHOF-1 and Z-DAAO@ZIF-8 and Z-DAAO@MAF-7 compared to ultra large pore SBA-15 silica ${ }^{[55]}$ and mesocellular silica foam MSU-F. ${ }^{[78]}$ (b) Recycling of DAAO@MAF-7 and DAAO@BioHOF-1. Activity after each cycle. The reaction was performed with $20 \mathrm{mg}_{\text {wet weight }} \mathrm{mL}^{-1}$ biocomposite, $10 \mathrm{mM}$ Dmethionine and $20 \mathrm{mM}$ HEPES $(\mathrm{pH} 8)$ at $30{ }^{\circ} \mathrm{C}$ after each cycle the biocomposite was separated by centrifugation and reused in a fresh reaction mixture.
Table 1. Comparison of apparent kinetic parameters for free (DAAO) and immobilized DAAO (DAAO@MAF-7 and DAAO@BioHOF-1) for D-methionine. At an initial Z-DAAO concentration of $1 \mathrm{mg} \mathrm{mL}^{-1}$ during the immobilization.

\begin{tabular}{ccccc}
\hline Catalyst & $\begin{array}{c}\mathbf{V}_{\text {max }} \\
{[\mu \mathrm{mol} \mathrm{min}} \\
1 \mathrm{mg}_{\text {enzyme }} \\
1]\end{array}$ & $\begin{array}{c}\boldsymbol{k}_{\text {cat }} \\
{\left[\mathrm{s}^{-1}\right]}\end{array}$ & $\begin{array}{c}\boldsymbol{K}_{\mathbf{m}} \\
{[\mathrm{mM}]}\end{array}$ & $\begin{array}{c}\boldsymbol{k}_{\text {cat }} / \boldsymbol{K}_{\mathbf{m}} \\
{\left[\mathrm{s}^{-1} \mathrm{mM}^{-1}\right]}\end{array}$ \\
\hline Z-DAAO & $50.1 \pm 0.8$ & $\begin{array}{c}40.6 \\
\pm 0.7\end{array}$ & $\begin{array}{c}1.264 \pm \\
0.111\end{array}$ & $16.1 \pm 2.9$ \\
& & $2.6 \pm$ & $1.960 \pm$ & $0.7 \pm 0.0$ \\
Z-DAAO@MAF-7 & $3.2 \pm 0.01$ & 0.0 & 0.083 & \\
& & 13.2 & $0.560 \pm$ & $11.8 \pm 1.2$ \\
Z-DAAO@BioHOF-1 & $16.3 \pm 0.1$ & \pm 0.0 & 0.034 & \\
\hline
\end{tabular}

The retention of enzyme activity in the Z-DAAO@MAF-7 composite and the loss of activity for Z-DAAO@ZIF-8 (Figure 4a) prompted further investigation. When incubated with the soluble Z-DAAO for $1 \mathrm{~h}$, the framework precursors of all three composites proved to be deleterious to enzyme activity (Figure S47). In particular $\mathrm{Zn}\left(\mathrm{NO}_{3}\right)_{2}$ (MAF-7) resulted in a greater loss in activity than $\mathrm{Zn}(\mathrm{OAc})_{2}$ (ZIF-8). However, such simple stability assays cannot reproduce the self-assembly conditions that lead to rapid composite formation ( $\leq 5 \mathrm{~min}$ ). Indeed, the evidence implies that reason for the inactive Z-DAAO@ZIF-8 is likely due to the microenvironment surrounding the enzyme in the solid composite. For example, FTIR analysis (Figure S16) shows a characteristic change in infrared band (band shift to higher wavenumber; single band $\rightarrow$ bifurcated band) ${ }^{[65-69]}$ in the amide I region of the spectrum that is indicative of more significant denaturation in ZDAAO@ZIF-8 compared to Z-DAAO@MAF-7 and the free enzyme. ${ }^{[59]}$

Finally, we analyzed the biological stability and the structural robustness of the Z-DAAO composites via recycling experiments of the HOF-based solid catalyst for D-Met oxidation (Figure S48S49) using surface aeration to supply $\mathrm{O}_{2}$. On the basis of specific activity of the framework-bound enzyme, the Z-DAAO@BioHOF1 showed excellent stability, with negligible loss of activity (ca. $20 \%$ ) over the first three reaction cycles (Figure $5 \mathbf{b}$ ), followed by a plateau. It is worth noting that for recycling tests of immobilized enzymes a decrease in specific activity of about $25 \%$ can be observed in the first cycle. ${ }^{[87]}$ In case of Z-DAAO@BioHOF-1, this may reflect that initially surface bound Z-DAAO could be readily released from the material (for the general case, see ref ${ }^{[26]}$ ). Stability tests show that after 10 cycles the weight and crystallinity of Z-DAAO@BioHOF-1 were maintained (Figure S50a-b). However, the particle morphology showed increased surface roughness (Figure S50c-d). Similar stability was observed for ZDAAO@MAF-7, however this biocomposite featured gradual decrease in specific activity to just $\sim 20 \%$ remaining in the last cycle. Furthermore these results show that the BioHOF-1-bound Z-DAAO was significantly more stable and more active than the MAF-bound Z-DAAO.

\section{Conclusion}

In conclusion, we presented a systematic evaluation of three crystalline, porous framework materials (BioHOF-1, ZIF-8 and MAF-7) for the aqueous one-pot immobilization of Z-DAAO, without the use of organic co-solvents (e.g. DMF ${ }^{[37,58]}$ ). BioHOF1 , a hydrogen-bonded organic framework, shows outstanding performance with respect to enzyme loading and retention of 
activity, exceeding both ZIF-8 MAF-7 and traditional immobilization carriers. Our results suggest that the surfacebinding module $Z_{\text {basic2 }}$ drives the active incorporation of the enzyme into the functional BioHOF-1 composite. Thus, modular approaches based on fusion proteins that involve $Z_{\text {basic2 }}$ as incorporator module could facilitate the biocomposite development with other enzymes. Despite the high loadings achieved, the enzyme catalyzes $\mathrm{O}_{2}$ dependent transformation without evidence of diffusional restrictions and shows excellent stability and can be cycled with negligible loss of activity. The outstanding performance characteristics of Z-DAAO@BioHOF-1 demonstrate potential scope for combining fusion proteins with BioHOF-1 for the preparation of a new generation of highly efficient heterogeneous biocatalysts.

\section{Acknowledgments}

We acknowledge financial support from TU Graz Lead Project (LP-03). CJD gratefully acknowledges funding from the Australian Research Council (DP200102411).

Keywords: D-amino acid oxidase $\cdot$ hydrogen-bonded organic frameworks • immobilization $\cdot$ metal-organic frameworks • porous carrier

[1] R. A. Sheldon, J. M. Woodley, Chem. Rev. 2018, 118, 801-838.

[2] E. L. Bell, W. Finnigan, S. P. France, A. P. Green, M. A. Hayes, L. J. Hepworth, S. L. Lovelock, H. Niikura, S. Osuna, E. Romero, K. S. Ryan, N. J. Turner, S. L. Flitsch, Nat Rev Methods Primers 2021, 1, 1-21.

[3] S. Wu, R. Snajdrova, J. C. Moore, K. Baldenius, U. T. Bornscheuer, Angew. Chem., Int. Ed. 2021, 60, 88-119.

[4] M. Vellard, Curr. Opin. Biotechnol. 2003, 14, 444-450.

[5] S. A. Farhadi, E. Bracho-Sanchez, S. L. Freeman, B. G. Keselowsky, G. A. Hudalla, Bioconjugate Chem. 2018, 29, 649-656.

[6] R. A. Sheldon, A. Basso, D. Brady, Chem. Soc. Rev. 2021, 50, 58505862 .

[7] M. Li, N. T. Blum, J. Wu, J. Lin, P. Huang, Adv. Mater. 2021, 33, 2008438.

[8] W. Liang, P. Wied, F. Carraro, C. J. Sumby, B. Nidetzky, C.-K. Tsung, P. Falcaro, C. J. Doonan, Chem. Rev. 2021, 121, 1077-1129.

[9] I. S. Kucherenko, O. O. Soldatkin, D. Y. Kucherenko, O. V. Soldatkina, S. V. Dzyadevych, Nanoscale Adv. 2019, 1, 4560-4577.

[10] H. Chen, O. Simoska, K. Lim, M. Grattieri, M. Yuan, F. Dong, Y. S. Lee, K. Beaver, S. Weliwatte, E. M. Gaffney, S. D. Minteer, Chem. Rev. 2020, 120, 12903-12993.

[11] V. D. Jäger, R. Lamm, K. Küsters, G. Ölçücü, M. Oldiges, K.-E. Jaeger, J. Büchs, U. Krauss, Appl. Microbiol. Biotechnol. 2020, 104, 7313-7329.

[12] G. Ölçücü, O. Klaus, K.-E. Jaeger, T. Drepper, U. Krauss, ACS Sustainable Chem. Eng. 2021, 9, 8919-8945.

[13] U. Roessl, J. Nahálka, B. Nidetzky, Biotechnol. Lett. 2010, 32, 341-350.

[14] P. T. Anastas, R. H. Crabtree, Green Catalysis, Volume 3: Biocatalysis, Wiley, 2014

[15] K. Buchholz, V. Kasche, U. T. Bornscheuer, Biocatalysts and Enzyme Technology, Wiley, 2012.

[16] Y. Dai, C. C. Liu, Angew. Chem., Int. Ed. 2019, 58, 12355-12368.

[17] H. H. Nguyen, S. H. Lee, U. J. Lee, C. D. Fermin, M. Kim, Materials 2019, 12, 121

[18] P. Pinyou, V. Blay, L. M. Muresan, T. Noguer, Mater. Horiz. 2019, 6, 1336-1358.

[19] J. M. Guisan, J. M. Bolivar, F. López-Gallego, J. Rocha-Martín, Eds. , Immobilization of Enzymes and Cells: Methods and Protocols, Springer US, 2020.

[20] J. Zdarta, A. S. Meyer, T. Jesionowski, M. Pinelo, Catalysts 2018, 8, 92.

[21] M. Romero-Fernández, F. Paradisi, Curr. Opin. Chem. Biol. 2020, 55, 18.

[22] S. Cantone, V. Ferrario, L. Corici, C. Ebert, D. Fattor, P. Spizzo, L. Gardossi, Chem. Soc. Rev. 2013, 42, 6262-6276.
[23] J. M. Bolivar, I. Eisl, B. Nidetzky, Catal. Today 2016, 259, 66-80.

[24] J. M. Bolivar, B. Nidetzky, Biochim. Biophys. Acta, Proteins Proteomics 2020, 1868, 140333.

[25] C. Garcia-Galan, Á. Berenguer-Murcia, R. Fernandez-Lafuente, R. C. Rodrigues, Adv. Synth. Catal. 2011, 353, 2885-2904.

[26] D. Faulón Marruecos, D. K. Schwartz, J. L. Kaar, Curr. Opin. Colloid Interface Sci. 2018, 38, 45-55.

[27] N. Carlsson, H. Gustafsson, C. Thörn, L. Olsson, K. Holmberg, B. Åkerman, Adv. Colloid Interface Sci. 2014, 205, 339-360.

[28] S. R. Batten, N. R. Champness, X.-M. Chen, J. Garcia-Martinez, S. Kitagawa, L. Öhrström, M. O’Keeffe, M. P. Suh, J. Reedijk, Pure Appl. Chem. 2013, 85, 1715-1724.

[29] I. Hisaki, C. Xin, K. Takahashi, T. Nakamura, Angew. Chem., Int. Ed. 2019, O, DOI 10.1002/anie.201902147.

[30] S. A. Boer, M. Morshedi, A. Tarzia, C. J. Doonan, N. G. White, Chem. Eur. J. 2019, 25, 10006-10012.

[31] R. J. Drout, L. Robison, O. K. Farha, Coord. Chem. Rev. 2019, 381, 151160.

[32] S. Huang, X. Kou, J. Shen, G. Chen, G. Ouyang, Angew. Chem., Int. Ed. 2020, n/a, DOI 10.1002/anie.201916474.

[33] S. Liang, X.-L. Wu, J. Xiong, M.-H. Zong, W.-Y. Lou, Coord. Chem. Rev. 2020, 406, DOI 10.1016/j.ccr.2019.213149.

[34] S. S. Nadar, L. Vaidya, V. K. Rathod, Int. J. Biol. Macromol. 2020, DOI 10.1016/j.ijbiomac.2020.01.240.

[35] H. Furukawa, K. E. Cordova, M. O’Keeffe, O. M. Yaghi, Science 2013 341, 1230444-1230444.

[36] W. Liang, F. Carraro, M. B. Solomon, S. G. Bell, H. Amenitsch, C. J. Sumby, N. G. White, P. Falcaro, C. J. Doonan, J. Am. Chem. Soc. 2019, 141, 14298-14305.

[37] G. Chen, S. Huang, Y. Shen, X. Kou, X. Ma, S. Huang, Q. Tong, K. Ma, W. Chen, P. Wang, J. Shen, F. Zhu, G. Ouyang, Chem 2021, DOI 10/gmf287.

[38] J. Tang, J. Liu, Q. Zheng, W. Li, J. Sheng, L. Mao, M. Wang, Angew. Chem., Int. Ed. 2021, n/a, DOI 10/gmjqn2.

[39] W. A. Border, J. W. Harry, E. S. Kamil, A. H. Cohen, J. Clin. Investig. 1982, 69, 451-461.

[40] N. K. Maddigan, A. Tarzia, D. M. Huang, C. J. Sumby, S. G. Bell, P. Falcaro, C. J. Doonan, Chem. Sci. 2018, 9, 4217-4223.

[41] O. Boutureira, G. J. L. Bernardes, Chem. Rev. 2015, 115, 2174-2195.

[42] Y. Zhang, K.-Y. Park, K. F. Suazo, M. D. Distefano, Chem. Soc. Rev. 2018, 47, 9106-9136.

[43] N. C. Dubey, B. P. Tripathi, ACS Appl. Bio Mater. 2021, 4, 1077-1114.

[44] M. J. Kummer, Y. S. Lee, M. Yuan, B. Alkotaini, J. Zhao, E. Blumenthal, S. D. Minteer, JACS Au 2021, 1, 1187-1197.

[45] X. Chen, J. L. Zaro, W.-C. Shen, Adv. Drug Delivery Rev. 2013, 65, 1357-1369

[46] J. M. Bolivar, B. Nidetzky, Langmuir 2012, 28, 10040-10049.

[47] L. Pollegioni, G. Molla, Trends Biotechnol. 2011, 29, 276-283.

[48] S. Moussa, M. R. V. Horn, A. Shah, L. Pollegioni, C. J. Thibodeaux, E. S. Ruthazer, J. Mauzeroll, J. Electrochem. Soc. 2021, 168, 025502.

[49] E. Rosini, P. D'Antona, L. Pollegioni, Int. J. Mol. Sci. 2020, 21, 4574.

[50] E. Jurrus, D. Engel, K. Star, K. Monson, J. Brandi, L. E. Felberg, D. H. Brookes, L. Wilson, J. Chen, K. Liles, M. Chun, P. Li, D. W. Gohara, T. Dolinsky, R. Konecny, D. R. Koes, J. E. Nielsen, T. Head-Gordon, W Geng, R. Krasny, G.-W. Wei, M. J. Holst, J. A. McCammon, N. A. Baker, Protein Sci. 2018, 27, 112-128.

[51] I. Dib, D. Stanzer, B. Nidetzky, Appl. Environ. Microbiol. 2007, 73, 331333.

[52] I. Dib, B. Nidetzky, BMC Biotechnol. 2008, 8, 72.

[53] J. Wiesbauer, J. M. Bolivar, M. Mueller, M. Schiller, B. Nidetzky, ChemCatChem 2011, 3, 1299-1303.

[54] J. M. Bolivar, B. Nidetzky, Biotechnol. Bioeng. 2012, 109, 1490-1498.

[55] J. M. Bolivar, V. Gascon, C. Marquez-Alvarez, R. M. Blanco, B. Nidetzky, Langmuir 2017, 33, 5065-5076.

[56] D. Valikhani, J. M. Bolivar, A. Dennig, B. Nidetzky, Biotechnol. Bioeng 2018, 115, 2416-2425.

[57] M. Hedhammar, S. Hober, J. Chromatogr. A 2007, 1161, 22-28.

[58] G. Chen, Z. Tang, X. Li, L. Tong, H. Yang, J. Wu, X. Zhang, T. Song, S. Huang, F. Zhu, G. Ouyang, Angew. Chem., Int. Ed. 2021, n/a, DOI 10/gmnn98. 
[59] W. Liang, H. Xu, F. Carraro, N. K. Maddigan, Q. Li, S. G. Bell, D. M. Huang, A. Tarzia, M. B. Solomon, H. Amenitsch, L. Vaccari, C. J. Sumby, P. Falcaro, C. J. Doonan, J. Am. Chem. Soc. 2019, 141, 2348-2355.

[60] R. Chen, J. Yao, Q. Gu, S. Smeets, C. Baerlocher, H. Gu, D. Zhu, W. Morris, O. M. Yaghi, H. Wang, Chem. Commun. 2013, 49, 9500-9502.

[61] K. S. Park, Z. Ni, A. P. Côté, J. Y. Choi, R. Huang, F. J. Uribe-Romo, H. K. Chae, M. O'Keeffe, O. M. Yaghi, Proc. Natl. Acad. Sci. U. S. A. 2006 , 103, 10186-10191.

[62] T. Stassin, I. Stassen, J. Marreiros, A. J. Cruz, R. Verbeke, M. Tu, H. Reinsch, M. Dickmann, W. Egger, I. F. J. Vankelecom, D. E. De Vos, R. Ameloot, Chem. Mater. 2020, 32, 1784-1793.

[63] F.-X. Coudert, ChemPhysChem 2017, 18, 2732-2738.

[64] J. Bandekar, Biochim. Biophys. Acta, Protein Struct. Mol. Enzymol. 1992, $1120,123-143$.

[65] F. Mallamace, C. Corsaro, D. Mallamace, S. Vasi, C. Vasi, G. Dugo, Comput. Struct. Biotechnol. J. 2015, 13, 33-37.

[66] D. Mallamace, E. Fazio, F. Mallamace, C. Corsaro, Int. J. Mol. Sci. 2018, 19, 3825.

[67] J. Kong, S. Yu, Acta Biochim. Biophys. Sin. 2007, 39, 549-559.

[68] D. M. Byler, H. Susi, in Fourier and Computerized Infrared Spectroscopy, International Society For Optics And Photonics, 1985, pp. 289-290.

[69] H. Yang, S. Yang, J. Kong, A. Dong, S. Yu, Nat. Protoc. 2015, 10, 382396.

[70] C. Hu, Y. Bai, M. Hou, Y. Wang, L. Wang, X. Cao, C.-W. Chan, H. Sun, W. Li, J. Ge, K. Ren, Sci. Adv. 2020, 6, eaax5785.

[71] C. L. Cooney, Science 1983, 219, 728-733.

[72] M. Andlar, I. Rezić, D. Oros, D. Kracher, R. Ludwig, T. Rezić, B. Šantek, J. Chem. Technol. Biotechnol. 2017, 92, 623-632.
[73] E. Romero, J. R. Gómez Castellanos, G. Gadda, M. W. Fraaije, A. Mattevi, Chem. Rev. 2018, 118, 1742-1769.

[74] J. Dong, E. Fernández-Fueyo, F. Hollmann, C. E. Paul, M. Pesic, S. Schmidt, Y. Wang, S. Younes, W. Zhang, Angew. Chem., Int. Ed. 2018, 57, 9238-9261.

[75] D. Holtmann, M. W. Fraaije, I. W. C. E. Arends, D. J. Opperman, F. Hollmann, Chem. Commun. 2014, 50, 13180-13200.

[76] J. M. Bolivar, B. Nidetzky, Molecules 2019, 24, 3460.

[77] A. Lorente-Arevalo, M. Ladero, J. M. Bolivar, Curr. Opin. Green Sustain. Chem. 2021, 100544.

[78] J. M. Bolivar, S. Schelch, T. Mayr, B. Nidetzky, ACS Catal. 2015, 5, 5984-5993.

[79] J. M. Bolivar, T. Consolati, T. Mayr, B. Nidetzky, Biotechnol. Bioeng. 2013, 110, 2086-2095.

[80] J. van Roon, R. Beeftink, K. Schroën, H. Tramper, Curr. Opin. Biotechnol. 2002, 13, 398-405.

[81] A. I. Benítez-Mateos, B. Nidetzky, J. M. Bolivar, F. López-Gallego, ChemBioChem 2018, 10, 654-665.

[82] Y. Pan, H. Li, J. Farmakes, F. Xiao, B. Chen, S. Ma, Z. Yang, J. Am. Chem. Soc. 2018, 140, 16032-16036.

[83] F. S. Aalbers, M. W. Fraaije, ChemBioChem 2019, 20, 20-28.

[84] K. Yu, C. Liu, B.-G. Kim, D.-Y. Lee, Biotechnol. Adv. 2015, 33, 155-164.

[85] R. C. Rodrigues, C. Ortiz, Á. Berenguer-Murcia, R. Torres, R. Fernández-Lafuente, Chem. Soc. Rev. 2013, 42, 6290-6307.

[86] P. J. Halling, Enzyme Microb. Technol. 1994, 16, 178-206.

[87] A. Sadana, Chem. Rev. 1992, 92, 1799-1818. 